International Journal of Production Technology and Management (IJPTM)

Volume 9, Issue 2, July-December, pp. 23-30, Article ID: IJPTM_09_02_002

Available online at

http://iaeme.com/Home/issue/IJPTM?Volume $=9 \&$ Issue $=2$

Journal Impact Factor (2018): 6.3287 (Calculated by GISI) www.jifactor.com

ISSN Print: 0976- 6383 and ISSN Online: 0976 - 6391

DOI: 10.34218/IJPTM.9.2.2018.002

(C) IAEME Publication

\title{
A STUDY ON THE MARINE ENGINEERS RETENTION STRATEGY BY THE SHIPPING COMPANIES IN INDIA
}

\author{
Dr.J.Rengamani \\ Associate Professor, AMET Business School, \\ AMET University, India
}

\begin{abstract}
Employee Retention involves taking measures to encourageemployees to remain in the organization for the maximum period of time. Ship manning companies are facing a lot of problems in sea staff retention these days. Hiring knowledgeable and experienced officers are essential for a shipping company. But retention is even more important than hiring. There is no dearth of opportunities for a talented person. There are many organizations which are looking for such employees. If a person is not satisfied by the job he is doing, he may switch over to some other more suitable job. In today's environment it becomes very important for organizations to retain their employees. Shipping is considered as one of the important modes of transporting goods to countries far and across. Ships make the shipping business going satisfying the various needs of the customers across the globe. Sea staff plays a very important role in the safe movement of these ships from one place to another. Thus, it becomes necessary to analyse the retention of sea staff at sea in modern day shipping activities with full of stringent regulations and requirements at work atmosphere and to get a clear picture of the shipping sector in the near future.
\end{abstract}

Keywords: Employees, Retention of Employees, Strategy, Job Rotation, Job Satisfaction.

Cite this Article: Dr. J. Rengamani, A Study on the Marine Engineers Retention Strategy by The Shipping Companies In India, International Journal of Production Technology and Management (IJPTM), 9(2), 2018, pp. 23-30.

$\mathrm{http}: / /$ iaeme.com/Home/issue/IJPTM?Volume=9\&Issue $=2$

\section{INTRODUCTION}

Marine Engineers retention refers to policies and practices companies use to prevent valuable employees from leaving their jobs. How to retain valuable employees is one of the biggest problem that plague companies in the competitive marketplace. Not too long ago, companies accepted the "revolving door policy" as part of doing business and were quick to fill a vacant job with another eager candidate. Nowadays, businesses often find that they spend considerable 
time, effort, and money to train an employee only to have them develop into a valuable commodity and leave the company for greener pastures. In order to create a successful company, employers should consider as many options as possible when it comes to retaining employees, while at the same time securing their trust and loyalty so they have less of a desire to leave in the future.

Marine Engineers retention involves taking measures to encourage sailing staff to remain in the company for the maximum period of time. Corporate is facing a lot of problem in employee retention these days. Hiring knowledgeable people for the job is essential for an employer. But retention is even more important than hiring. There is no dearth of opportunities for talented person. There are many companies which are looking for talented and experienced sailing staff. If a person is not satisfied by the job he is doing, he may switch over to some other more suitable job. In today's environment it becomes very important for shipping companies to retain their sea staff.

The process of employee retention benefits an organization in many ways

- The Cost of Turnover: The cost of sea staff turnover adds hundreds of thousands of money to a company's expenses. While it is difficult to fully calculate the cost of turnover (including hiring costs, training costs and productivity loss), industry experts often quote $25 \%$ of the average employee salary as a conservative estimate.

- Loss of Company Knowledge: When an employee leaves, he takes with him valuable knowledge about the ship manning company, ship management policies \& standards, charterers and past history. Often much time and money has been spent on the employee in expectation of a future return. When the employee leaves, the investment is not realized.

- Turnover leads to more turnovers: When a sea staff terminates, the effect is felt throughout the fleet. Other sailing staffs are often compelled to pull along a lengthy extended contract waiting for their relievers. Co-workers are often required to pick up the slack. The unspoken negativity often intensifies for the remaining staff.

- Goodwill of the company: The goodwill of a company is maintained when the attrition rates are low. Higher retention rates motivate potential and competent officers to join the Company.

- Regaining efficiency: If a sailing staff resign, then good amount of time is lost in hiring a new employee and then training him/her and this goes to the loss of the company directly which many a times goes unnoticed. And even after this, one may not assure the same efficiency from the new employee

\section{LITERATURE REVIEW}

According to Get Les Mckeown's employee retention is defined as "a systematic effort by employers to create and foster an environment that encourages current employees to remain employed by having policies and practices in place that address their diverse needs. Also of concern are the costs of employee turnover (including hiring costs. productivity loss). Replacement costs usually are 2.5 times the salary of the individual. The costs associated with turnover may include lost customers, business and damaged morale. In addition there are the hard costs of time spent in screening, verifying credentials, references, interviewing, hiring, and training the new employee just to get back to where you started".

In the words of Oliver Sheldon 'No industry can be rendered efficient as long as the basic fact remains unrecognised that is principally human. It is not the mass of technical process and machines but a body of men. It is not a complex matter but a complexity of humanity. It fulfils its function not by virtue of small impersonal force but by human energy'. 
Employees are the most valuable assets of an organization. Their significance to organizations calls for not only the need to attract the best talents but also the necessity to retain them for a long term. This paper focuses on reviewing the findings of previous studies conducted by various researchers with the aim to identify determinants factors of employee retention. This research closely looked at the following broad factors: development opportunities, compensation, work-life balance, management/leadership, work environment, social support, autonomy, training and development. The study reached the conclusion that further investigations need to be conducted regarding employee retention to better comprehend this complex field of human resource management. (Bodjrenou Kossivi, Ming Xu, Bomboma Kalgora, 2016)

Many experts agree that employees' retention policies are aimed at addressing the various needs of employees to enhance their job satisfaction and reduce the substantial costs involved in hiring and training new staff. It is essential for an organization to maintain corporate strategic advantage by retaining the hardworking and talented employees. Hence, managers must understand the difference between a valuable employees and an employee who does not contribute much to the organization so that they can design appropriate strategies to retain the potential employees. These strategies may range from lucrative rewarding packages to involving employees in every sphere of the functioning of the organization (Mak and Sockel, 2001).

Many experts are of the view that employees are the staying power of any organization so organizations necessitate taking initiative to implement the employees' motivation process, thereby enhancing the overall employees' performance by providing quality products and offering excellent services. It is also required to realize the employee turnover intent. Around fifteen percent of the workforce intends to leave, which are likely to result in actual turnover if mitigating strategies are not put in place. It is less expensive to retain the employees than to recruit, train and place new ones. Therefore, every organization will have necessary measures to fill employee vacancies and need to develop robust retention strategies to prevent further employees leaving. As a consequence, the intent of this paper in discovering the factors and narrating them to the study is to present a general viewpoint of what the organization necessitates to identify and anticipate, as well as what are the diverse streets available for future reflection to deal with major issues relating to employee turnover. (Chowdhury Abdullah Al Mamun and Md. Nazmul Hasan, 2017)

Human resources are complex and not easy to understand. These are the assets which can make as well as break an organization. Retaining them will help in the long-term growth of an organization and will also add to their goodwill. But the most difficult task faced by an organization today is retaining as well as satisfying these resources. Although the research paper tried its level best to reveal the various research works done and the contributions forwarded by various researchers in the area of employee retention and job satisfaction, but still much scope remains for more exploration in the field of employee retention and it by taking into consideration the factors like compensation practices, leadership and supervision, career planning and development, alternative work schedule, working conditions, flexible working hours etc. Needless to say that these efforts should be conducted by HR professionals. (Bidisha Lahkar Das, Dr. Mukulesh Baruah, 2013)

This study uses a sample of 47 high-growth small firms to examine the understudied topic of employee retention. We found that firms reporting very low annual voluntary turnover ( 0 $2 \%$ ) rates engaged in creating a positive work environment, provided employees more freedom and flexibility, offered ample employee involvement and opportunities for growth; were clear about the processes associated with compensation and benefits, and frequently communicated with and provided assistance to their employees. Firms reporting turnover higher than $10 \%$ for 
the past year described their retention practices in much diminished frequency and richness along these same dimensions. Given that these firms were all part of a pool of 77 high growth small companies (over $\$ 1$ million annual revenue, less than 12 years old and compound annual growth greater than $15 \%$ ), retention of intellectual capital would be a prime issue. Industry differences among the companies are explored and theoretical and practical implications are discussed. (Bruce H. Kemelgor, William R. Meek, 2008)

\section{RESEARCH OBJECTIVES}

The research objectives of the study are given below:

- To analyse Personal and Organisational factors which are influencing seafarer retention

- To analyse Demographic trends that lead to successful retention and utilizing the results of these, to predict the retention strategies for the future.

\section{RESEARCH HYPOTHESIS}

In order to achieve the objectives, this article is organized around the following working hypotheses:

- $\mathrm{H}_{1}$ : There is a significant difference in the factors affecting the retention of seafarers.

- $\mathrm{H}_{2}$ : There is a significant difference in the organisational factors affecting the retention of seafarers

\section{METHODOLOGY}

The main aim of this study is to find out the feelings of the seafarers about the employee retention. Hence more emphasis is given to primary data collection. The main purpose of primary data collection is to get first-hand information from the respondents. It also ensures certain degree of authenticity of the data collected as we are able to glimpse into the mind of the respondents. The study is carried out with a help of structured questionnaire consisting multiple choice questions which is sent to the seafarers of Indian origin. The target population of the current study happens to be the seafarers sailing in the Merchant ships. Here Samples are collected based on stratified sampling with the sample size of 150 by using online questionnaire. The seafarers opinion was obtained on a five-point scale from 1 (strongly disagree) to 5 (strongly agree). The questionnaire designed for the evaluation of subjective perception of the Indian seafarers. The Cronbach's alpha values were calculated to check the consistency and reliability of data collected through the survey. The Conceptual Model regarding the retention of Employees is given in Fig-1: 


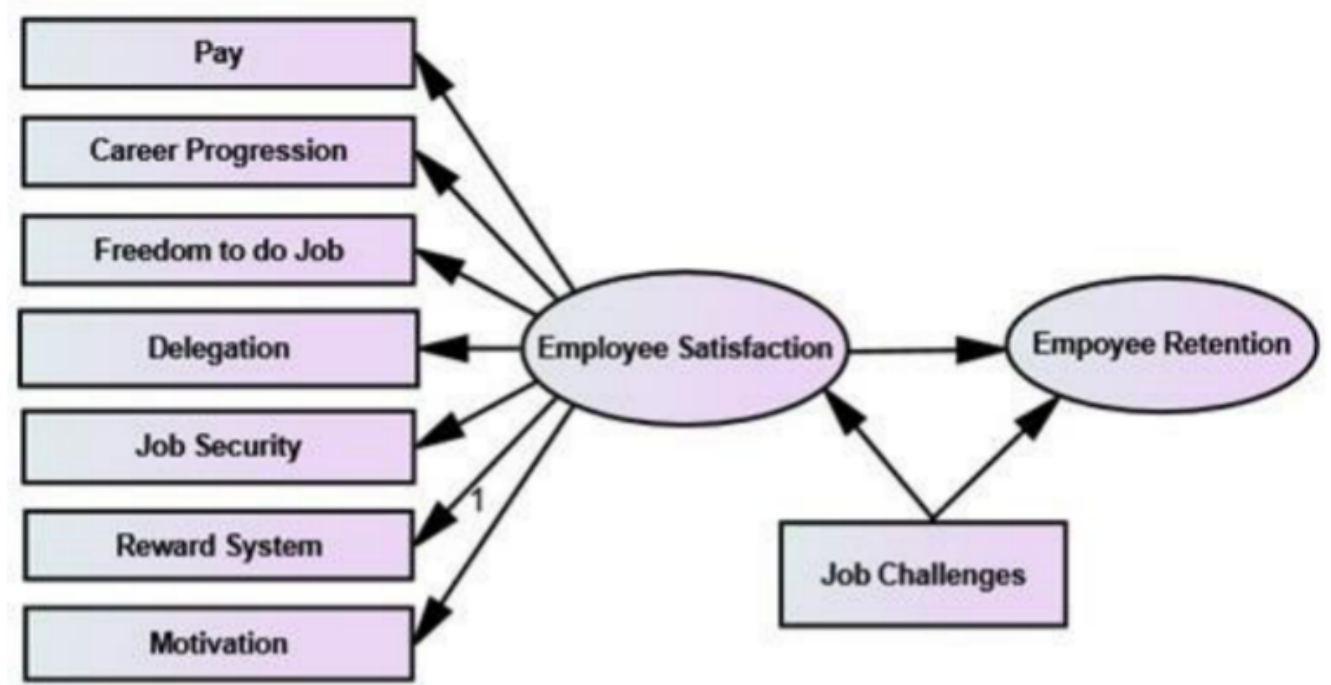

Figure 1 Employee Retention Model (Source: Survey Questionnaire)

\section{ANALYSIS OF DATA}

The demographic data analysis of the seafarers' are discussed below.

Table 1 Demographic Data Analysis

\begin{tabular}{|c|c|c|}
\hline Descriptive Factors & Frequency & Percentage \\
\hline A. Gender & & \\
Male & 138 & 92 \\
Female & 12 & 8 \\
\hline Marital Status & & \\
Married & 48 & 59 \\
Unmarried & 17 & 31 \\
Others & 15 & 10 \\
\hline Education & 42 & 28 \\
Diploma & 84 & 56 \\
Graduate & 8 & 5 \\
Post-graduate & 16 & 11 \\
Others & 62 & 41 \\
\hline Job Function & 54 & 36 \\
Chief Engineer & 22 & 15 \\
Second Engineer & 12 & 8 \\
Third Engineer & \\
Motormen and Oiler &
\end{tabular}

From Table-1, it can be inferred that out of 150 respondents, $92 \%$ of the respondents are male seafarers followed by $8 \%$ of female seafarers. Because of the nature of job on board the ships, it is clearly evident that the male seafarers are more predominant than the female seafarers. $56 \%$ of the respondents are graduates and $28 \%$ of the respondents hold diploma qualifications. The survey was administered to $41 \%$ of chief engineers, $36 \%$ of second engineers and $15 \%$ of third engineers.

The marine engineers were studied through the 5-point Likert Scale. In order to test the consistency and reliability of the scale, Cronbach's Alpha values were calculated. All the 
Cronbach's Alpha values were above 0.92 and hence it can be inferred that the scales are consistent and reliable.

In order to test the working hypotheses, the results of the survey questionnaire survey regarding the opinion of the marine engineers shows that the p-values of all the factors are less than 0.05 (Table-2). This clearly indicates that there is a significant difference in the mean values of the factors of employee retention such as Good Pay, Provides information needed to perform job, Scope for contribution to the company, Opportunities provided by superior to develop new competencies, Company's Career Progression System, Challenging work, Your superior's role in counselling and mentoring, Relationship with your colleagues / Interdepartmental relations, Equitable Compensation, Level of freedom to discharge your duties, Delegation of power to discharge your duties effectively, Job Content, Your future prospects in the company, Job Security, Employees welfare schemes initiated by the company, Reward System, Effectiveness of communication system in your company, Motivation of sailing staff by the Management, Organisation's policies and procedures, Performance Appraisal System, Grievance Handling Procedure/System, Training and development system of your organisation.

Table $2 \mathrm{t}$-test values for testing the factors of retention

\begin{tabular}{|c|c|c|}
\hline Factors of Retention & t-test & p-values \\
\hline Good Pay & 2.15 & 0.007 \\
\hline Provides information needed to perform job & 2.59 & 0.002 \\
\hline Scope for contribution to the company & 2.45 & 0.012 \\
\hline $\begin{array}{c}\text { Opportunities provided by superior to develop new } \\
\text { competencies }\end{array}$ & 2.85 & 0.024 \\
\hline Company's Career Progression System & 2.56 & 0.012 \\
\hline Challenging work & 2.58 & 0.014 \\
\hline Relationship with your colleagues / Inter-departmental relations & 3.11 & 0.024 \\
\hline Equitable Compensation & 3.22 & 0.021 \\
\hline Level of freedom to discharge your duties & 3.54 & 0.018 \\
\hline Job Content & 3.12 & 0.002 \\
\hline Jobation of power to discharge your duties effectively & 3.45 & 0.005 \\
\hline Your future prospects in the company & 3.22 & 0.007 \\
\hline Recurity & 3.14 & 0.008 \\
\hline Employees welfare schemes initiated by the company & 2.52 & 0.012 \\
\hline Effectiveness of communication system in your company & 2.56 & 0.014 \\
\hline Motivation of sailing staff by the Management & 2.45 & 0.018 \\
\hline Organisation's policies and procedures & 2.75 & 0.011 \\
\hline Performance Appraisal System & 3.25 & 0.021 \\
\hline Grievance Handling Procedure/System & 3.65 & 0.012 \\
\hline Training and development system of your organisation & 2.65 & 0.004 \\
\hline
\end{tabular}

The study reveals the fact that the factors such as Pay, Career Progression, Freedom to do Job, Delegation, Job Security, Reward System and Motivation are the core factors which are responsible for retaining the marine engineers. 


\section{CONCLUSION}

One of the greatest challenges in today's business world is to stay up to speed in a time of technological growth. Companies spend a huge amount of money to remain competitive. As we move ahead at an increasing pace in the area of technology, we are unfortunately facing an increased shortage of highly skilled and experienced sea staff. Sea staff retention is a concern for companies in this strong job market. There are a great number of employment opportunities for talented professionals and the higher the experience and loyalty of an employee, the greater is the demand for his services. The cost to replace an employee is becoming more documented and the news is not good for employers. It costs a great deal to replace an employee. Though Employee retention has been vividly researched by many authors, there is still a larger scope to undertake a study in this area since it is very difficult to generalise the factors of the employee retention in general especially for retention of sailing staff. Job satisfaction is the most important factor of employee retention. The factors influencing human being and their job satisfaction vary drastically between one nature of job to another, which broadens the scope of research in this area. The level of job satisfaction differs from person to person depending upon the situation and individual differences in personality. Even the sea staffs in a highly paid company have job dissatisfaction due to various factors and this leads to his leaving the company.

\section{REFERENCES}

[1] Bidisha Lahkar Das, Dr. Mukulesh Baruah, Employee Retention: A Review of Literature, IOSR Journal of Business and Management (IOSR-JBM), e-ISSN: 2278-487X, p-ISSN: 2319-7668. Volume 14, Issue 2 (Nov. - Dec. 2013), PP 08-16.

[2] Bidisha Lahkar Das, Employee Retention: A Review of Literature, Research Gate, 2013.

[3] Bodjrenou Kossivi, Ming Xu, Bomboma Kalgora, Study on Determining Factors of Employee Retention, Open Journal of Social Sciences, 2016, 4, 261-268

Glanz, B.P. (2002). Handle with care: Motivating and Retaining Your Employees. New York: McGraw-Hill.

[4] Bruce H. Kemelgor, William R. Meek, Employee Retention in Growth-Oriented Entrepreneurial Firms: An Exploratory Study, Journal of Small Business Stretegy, 2008

[5] Chowdhury Abdullah Al Mamun and Md. Nazmul Hasan (2017). Factors affecting employee turnover and sound retention strategies in business organization: a conceptual view. Problems and Perspectives in Management, 15(1), 63-71.

[6] Cyril C. George, J. Rengamani, International Trade Importance Trends and Approaches, Indian Journal of Public Health Research \& Development, March 2018, Vol.9, No. 3.

[7] Hausknecht, J. P., \& Trevor, C. O. (2011). Collective turnover at the group, unit, and organizational levels: Evidence, issues, and implications. Journal of Management, 37(1), 352-388.

[8] Hausknecht, J. P., Rodda, J., \& Howard, M. J. (2009). Targeted employee retention: Performance-based and job-related differences in reported reasons for staying. Human Resource Management, 48(2), 269-288.

[9] Hayton, J.C. (2003). Strategic human capital management in SME's: An empirical studyof entrepreneurial performance. Human Resources Management, 42(4): 375-391.

[10] Heavey, A. L., Holwerda, J. A., \& Hausknecht, J. P. (2013). Causes and consequences of collective turnover: A meta-analytic review. Journal of Applied Psychology, 98(3)

[11] Heneman, R.L. \& Tansky, J.W. (2002). Human resource management models for entrepreneurial opportunity: Existing knowledge and new directions. In: Katz, J. and Welbourne, T. (eds). Managing people in entrepreneurial organizations. Amsterdam: JAI Press. 
[12] Henricks, Mark (2006). Are you afraid your key employees are ready to walk? Here's what you can do to hold on to your most valuable players. Entrepreneur 1 April 2006, 84.

[13] Hom, P. W., Roberson, L., \& Ellis, A. D. (2008). Challenging Conventional Wisdom About Who Quits: Revelations From Corporate America. Journal Of Applied Psychology, 93(1), $1-34$.

[14] Hom, P.W.\& Kinicki, A.J. (2001). Towards a greater understanding of how dissatisfaction drives employee turnover. Academy of Management Journal, 44(5): 975-987.

[15] Hornsby, J.S. \& Kuratko, D.F. (2003). Human resource management in U.S. small businesses: A replication and extension. Journal of Developmental Entrepreneurship, 8(1): 73-92.

[16] J, D. W., \& Arora, S. (2004). Measuring retention rather than turnover: A different and complementary HR calculus. HR.Human Resource Planning, 27(3), 6-9.

[17] Jayan, R., Shameem, A., An empirical investigation about quality of work culture in logistics firms in Chennai, International Journal of Mechanical Engineering and Technology, 2017 .

[18] Kelvin M MwitaEliza MwakasangulaOscar Tefurukwa, The Influence of Leadership on Employee Retention in Tanzania Commercial Banks, Research Gate, 2018

[19] Kumar, A., Shameem, A., Distribution, logistics and management of channel partners in cement industry, International Journal of Applied Business and Economic Research, 2017.

[20] Mak, B. \& Sockel, H. (2001). A Confirmatory Factor Analysis of IS Employee Motivation and Retention. Information \& Management, 38, pp. 265-276.

[21] Marie Rose Muir, Lin Li, What are the Top Factors That Drive Employee Retention and are There Demographic (Gender, Generation, Ethnicity, Geography, etc.) Differences in These Factors?

[22] Poongavanam, S., Prasad, R.R., Srinivasan, R., Rengamani, An empirical study on civil construction workers labour welfare facilities in Chennai, International Journal of Civil Engineering and Technology, 2017

[23] Rajasekar, D., Krishna Sudheer, A., Raghunadha Reddy, P., A study on employee empowerment in indian corporate sector, International Journal of Civil Engineering and Technology, 2017

[24] Rengamani, J., Achieving project success for construction professionals to categorize significant project management innovations and expertise, International Journal of Supply Chain Management, 2018

[25] Rengamani, J., Agile improvement scheme utilized farmland information framework revisions of demand management, International Journal of Supply Chain Management, 2018

[26] Retention: How do I calculate retention? Is retention related to turnover? SHRM,(2012).

[27] Snell, A. (2009). Tackling the challenges of employee engagement. Strategic HR Review, 8(2), 37-38.

[28] Vandenberg, R. J., Richardson, H. A., \& Eastman, L. J. (1999). The impact of high involvement work processes on organizational effectiveness: A second-order latent variable approach. Group \& Organization

[29] Whitener, E. M. (2001). Do "high commitment" human resource practices affect employee commitment? A cross-level analysis using hierarchical linear modeling. Journal of Management, 27(5), 515-535. 